Systemy Logistyczne Wojsk

Zeszyt 55 (2021)

ISSN 1508-5430, s. 101-120

DOI:

Military Logistics Systems

Volume 55 (2021)

ISSN 1508-5430, pp. 101-120

DOI:
Instytut Logistyki Wydział Bezpieczeństwa, Logistyki i Zarządzania Wojskowa Akademia Techniczna w Warszawie

Institute of Logistics Faculty of Security, Logistics and Management Military University of Technology

in Warsaw

\title{
Analysis of aircraft equipment requirements to conduct RNP APCH approach operation
}

\section{Analiza wymagań wyposażenia statku powietrznego do prowadzenia operacji podejścia RNP APCH}

\author{
Anna Kwasiborksa \\ anna.kwasiborska@pw.edu.pl; ORCID: 0000-0002-3285-3337 \\ Politechnika Warszawska, Zakład Inżynierii Transportu Lotniczego, Polska \\ Sylwester Gładyś \\ sylwester.gladys@pw.edu.pl; ORCID: 0000-0003-0528-0876 \\ Politechnika Warszawska, Zakład Inżynierii Transportu Lotniczego, Polska \\ Krzysztof Banaszek \\ kabana@tlen.pl; ORCID: 0000-0002-6134-9025 \\ Faculty of Transport, Polish Air Navigation Services Agency, Polska \\ Jerzy Manewrowski \\ jerzy.manewrowski@pw.edu.pl; ORCID: 0000-0003-3556-3885 \\ Politechnika Warszawska, Zakład Inżynierii Transportu Lotniczego, Polska \\ Maciej Roś \\ maciej_ros@wp.pl; ORCID: 0000-0001-5890-3841 \\ Politechnika Warszawska, Zakład Inżynierii Transportu Lotniczego, Polska
}

\begin{abstract}
Aircraft traffic is constantly analyzed due to the issues of airspace and airport capacity. An important area is the approach to landing of aircraft at a given airport with the use of navigation aids. Navigation devices and systems are adapted to the legal requirements of European and international organizations. The use of the GNSS system with appropriate augmentation (ABAS or SBAS) defined as
\end{abstract}


RNP APCH approaches is authorized for operational use during landing approaches. Their introduction resulted in the emergence of a number of benefits. The authors analyzed the requirements of the aircraft on-board equipment necessary to perform RNP APCH approaches. The research goal is to evaluate the RNAV on-board equipment of aircraft on the example of three air carriers (as of December 2018). The hypothesis was verified by estimating the high level of on-board RVAV equipment of the aircraft. The method of analysis was applied using the CNS Dashboard application provided by Eurocontrol. It indicates the declared navigational capabilities of airplanes based on ICAO flight plans sent by carriers to the Network Manager correlated with the PRISME Fleet 2 aircraft database. using the ABAS system ( $96 \%$ of respondents). On the other hand, none of the aircraft had the required equipment to use SBAS during landing. Based on the examination of documents and observation of the research area, it can be concluded that air carriers more and more often equip their aircraft with the required modules of RNP APCH landing approaches.

Keywords: approach, RNPAPCH, Global Navigation Satellite System, Satellite Based Augmentation System

Abstrakt. Ruch statków powietrznych jest ciągle analizowany z uwagi na problematykę pojemności przestrzeni powietrznej i przepustowości portów lotniczych. Ważnym obszarem jest podejście do lądowania statków powietrznych na dane lotnisko z wykorzystaniem pomocy nawigacyjnych. Urządzenia i systemy nawigacyjne są dostosowywane do wymagań prawnych organizacji europejskich i międzynarodowych. Do użytku operacyjnego podczas podejść do lądowania dopuszczono możliwość korzystania z systemu GNSS wraz z odpowiednią augmentacją (ABAS lub SBAS) określoną jako podejścia RNP APCH. Ich wprowadzenie skutkowało w pojawieniu się szeregu korzyści. Autorzy podjęli się analizy wymagań wyposażenia pokładowego statków powietrznych niezbędnego do wykonywania podejść RNP APCH. Celem naukowym jest ocena wyposażenia pokładowego RNAV statków powietrznych na przykładzie trzech przewoźników lotniczych (stan na grudzień 2018r.). Weryfikacji poddano hipotezę szacując wysoki stopień wyposażenia pokładowego RVAV statków powietrznych. Zastosowano metodę analizy wykorzystując aplikację CNS Dashboard udostępnionej przez Eurocentów. Wskazuje ona zadeklarowane możliwości nawigacyjne samolotów na podstawie planów lotu ICAO przesyłanych przez przewoźników do Network Managera skorelowanych z bazą danych statków powietrznych PRISME Fleet 2. W wyniku przeprowadzonej analizy, można zauważyć, że prawie wszystkie badane statki powietrzne miały wymaganą certyfikację do przeprowadzania podejść RNP APCH z użyciem systemu ABAS ( $96 \%$ badanych). Z drugiej strony żaden z samolotów nie miał wymaganego wyposażenia do wykorzystywania systemu SBAS podczas lądowania. Na podstawie badania dokumentów i obserwacji obszaru badawczego można stwierdzić, że przewoźnicy lotniczy coraz częściej wyposażają swoje statki powietrzne w wymagane moduły podejściach do lądowania typu RNP APCH.

Słowa kluczowe: podejście do lądowania, RNPAPCH, Globalny System Nawigacji Satelitarnej, Satelitarne Systemy Wspomagające

\section{Abbreviations}

ABAS - Aircraft-based augmentation system

ASE - Altimetry System Error

APV - Approach with Vertical Guidance

CNS - Communications, navigation and surveillance

EGNOS - The European Geostationary Navigation Overlay Service

GLONASS - Global Orbiting Navigation System

GNSS - the Global Navigation Satellite System

HCE - Horizontal Coupling Error

FTE - Flight Technical Error

ICAO - International Civil Aviation Organisation 
LNAV - Localizer Performance with Vertical Guidance

NAVSTAR - Navigation Satellite Timing and Ranging

NPA - Non-Precision Approach

PBN - Performance Based Navigation

RNAV - Area navigation

RNP - Required Navigation Performance

SBAS - Satellite Based Augmentation System

WAAS - Wide Area Augmentation Systems

VNAV - Equipment Error

TTSE - Vertical Total System Error

\section{Introduction}

The start of the US NAVSTAR GPS satellite navigation system and the Russian GLONASS counterpart have been recorded in the military area. Only after some time was introduced for civilian purposes. The use of GNSS technology in air navigation has brought a breakthrough in the implementation of all phases of flight, and in particular, it enabled the RNAV landing approach. However, this requires a signal with higher parameters than for route navigation. Hence, there is a need for augmentation and one of three solutions: ABAS, SBAS, GBAS. The availability of ABAS and GBAS mainly depends on air operators, airport managers or air traffic management agencies. Making SBAS signal available for use requires making investments on a continental scale. EGNOS operates in Europe and on other continents SBAS systems can be distinguished, such as: American WAAS, Japanese MSAS or Indian GAGAN. The aim of the study is to analyze the requirements for the equipment of aircraft for RNAV landing approach operations and to evaluate the equipment of the aircraft with the necessary devices. Such equipment is necessary for the safe and correct execution of the final phase of flight based on the global navigation satellite system. The article presents the essence of area navigation with reference to Annex 10 of ICAO. The requirements for avionics used in aircraft for RNP APCH operations as well as four basic parameters with guidelines to be met are also described. In the research area, a hypothesis was adopted estimating the RVAV on-board equipment of the aircraft at the level of 5\%. The analysis method was applied using the CNS Dashboard application provided by Eurocontrol. It indicates the declared navigation capabilities of airplanes flying to European airports in a given period on the basis of ICAO flight plans sent by carriers to the Network Manager (air traffic management network) correlated with the PRISME Fleet 2 aircraft database. The research was carried out on the basis of scheduled flights of three airlines marked as A, B and C, which operated at Chopin Airport in December 2018. 
The results of the analysis were presented and the aircraft equipment in the field of landing approach operations was assessed. Research in this area is necessary because they relate to the aspects of safety, efficiency, reliability, cost reduction and reducing the negative impact on the environment.

\section{Literature review}

Area navigation RNAV has been defined in Annex 10 to the Convention on International Civil Aviation as follows "A method of navigation which permits aircraft operation on any desired flight path within the coverage of ground- or space-based navigation aids or within the limits of the capability of self-contained aids, or a combination of these" (ICAO, 2018. Annex 10, Volume I. Radio Navigation Aids, Seventh Edition).

The equipment of most aircraft with high-performance RNAV area navigation systems, and in particular the introduction of the Global Navigation Satellite System (GNSS), made it possible to use this technology during landing approaches. This allowed to significantly improve safety by providing pilots with better situational awareness of the position of their aircraft (Boukfaoui, 2015). As a result, the risk of a controlled flight to the ground has been reduced. Area navigation also allowed for an increase in the number of operations performed on runways not equipped with precision approach systems by increasing their availability during unfavorable weather conditions.

There are three types of instrumental approach procedures:

- Precision approach (PA) - it is the final phase of the approach to landing, which is performed according to instrument landing systems ensuring horizontal and vertical guidance on a geometrically defined continuous descent path (eg ILS, GLS, MLS). These procedures are published with the absolute / decision height (DA / H).

- Approach with Vertical Guidance (APV) - this is the most recent type of approach that can be carried out using RNAV area navigation providing LNAV horizontal guidance with VNAV vertical guidance. There are two types of such an approach - APV Baro VNAV and APV SBAS. These procedures are published with the Altitude/Decision Height (DA/H) (Guillet, 2019b).

- Non-Precision Approach (NPA) - uses conventional navigation aids such as NDB, VOR and DME to bring the aircraft to a point where the runway is in view and a visual landing can be performed. NPA procedures, which do not include vertical guidance, used to require multiple level-offs at step down fixes during the approach (Eurocontrol, 2012). 
APV procedures allow you to descend to the DA/H decision altitude/height as with precision approaches. This allows the minima values to be reduced compared to $\mathrm{MDA} / \mathrm{H}$, which increases the availability of landings at a given airport. In addition, safety is improved by having a positive impact on the pilot's situational awareness. Breakdown of RNAV landing approach procedures with horizontal and vertical guidance:

- APV Baro VNAV - RNAV approach procedures where vertical guidance is provided by a barometric altimeter. Allows you to descend to the LNAV/ VNAV decision on the approach sheet. Vessels equipped with SBAS can also perform APV Baro VNAV procedures with approval.

- APV SBAS - RNAV approach procedures where vertical guidance is provided by a GNSS receiver with an augmentation system based on additional SBAS satellite signals. It enables the descent to the level of the LPV decision on the approach sheet (Bousquet, Jacolot and Roturier, 2019).

The APV Baro-VNAV descent profile is established as a geometric path with a constant approach angle. The final descent path begins when the aircraft is on the vertical guidance plane (usually a point close to the FAF) and ends $50 \mathrm{ft}$ above the runway threshold. For APV SBAS approaches, final approach data is contained in the FAS DB final approach segment data block. The descent path profile is defined there, not calculated as for barometric altimeter approaches. It is very important for the APV Baro VNAV to correctly set the barometric altimeter as this is what the vertical guidance is based on. Additionally, the air temperature is also influenced by the limits of which are included in the approach chart.

RNP (Required Navigation Performance) is a type of RNAV-based navigation that additionally requires monitoring of characteristics and warning of abnormalities. After the RNP prefix, a number is given that determines the accuracy of navigation (Eurocontrol [6]). For example, RNP 1 means that the navigation error (difference between the displayed position and the actual position of the aircraft) for at least $95 \%$ of the flight duration can be 1 NM in any direction. All types of RNAV landing approaches require an abnormality monitoring and warning system (ABAS, SBAS or GBAS), so they came to be referred to as RNP APCH (APCH approach) (Guillet, 2019a). Currently, GNSS-based approach procedures are marked differently on the approach charts. Because of this, various inaccuracies have appeared.

ICAO has therefore decided to standardize the terminology to include guidelines in the document "Area Navigation (RNAV) to Required Navigation Performance (RNP) Instrument Approach Chart Depiction". Any procedure currently labelled RNAV that meets the requirements of RNP APCH or RNP AR APCH must be completed by December 1, 2022. renamed the RNP procedure. 
Improving the approach operation is a vital topic in line with the trend of increasing the efficiency of air transport. Preliminary works on RNP are present in the literature. Dauterman et al. (2015) designed and tested two RNP procedures at the airports of Saarbrücken and Egelsbach. Research show that the track can be followed with a precision of below 0.1 miles. Novák et al. (2019) present the issue of GNNS GPS L1 signal interference on the base of experimental measurements at the Žilina airport, where two sources of GPS L1 signal interference are placed. Hasegawa et al. (2015) present optimization method to plan approach procedure in terms of fuel efficiency. The route is parameterized by position of each waypoint and speed above them. Optimization is based on genetic algorithm. These works show that the topic is explored, but it is also quite new and requires development.

The RNP is the subject of research in the organisational and optimisation layer. The selected works in this area can be mentioned as a representative sample. Kwasiborska (2017) presented the research on sequencing landing aircraft processes to optimise the schedule. Zieja, Smoliński, and Gołda (2015) discuss information systems, mainly based on artificial intelligence, as a tool for supporting the management of aircraft flight safety, including approach. The evolution methods are used in this area for management of aircraft management (Kowalski et al. 2021). Gołda, Zawisza, and Izdebski (2021) also presented methods based on simulation tools which are examples of approach modelling and optimisation. Gołda and Zieja discuss risk analysis in air transport, while Rudyk et al. (2019) touch on the safety factor in fleet management. Approach realisation also influences ground traffic planning, and this is two-way relation, as discussed by Gołda (2018) in. Approach planning and realisation is also a factor influencing the environment through the noise and exhaust gas emission. This problem was discussed by Kwasiborska and Skorupski (2017), Pyza et al. (2018), Jacyna et al. (2017) or touched by Jacyna et. al (2018) in. All research conducted around airport operations, apart from the efficiency and environmental factors, aims to increase the safety of air operations. Kaleta and Skorupski (2019) implement fuzzy inference to analyse LPV-200 procedures influence on air traffic safety.

The literature items presented above touch selected fragments of the issues discussed in the article, but all are based on organisational methods. Meanwhile, the paper discusses the emerging solution, with an empty literature base to argue with. Thus, the authors hope that this work will give some input to a new discussion.

The remainder of the article is worded as follows. Chapter 2 will discuss parameters characterising the technical requirements for RNP APCH approaches, and Chapter 3 will discuss RNP AR APCH operations. Chapter 4 is devoted to analysing aircraft $\mathrm{PBN}$ equipment, while Chapter 5 presents 5 . conclusions and proposals for further actions in the field of RNAV landing approach operations. 


\section{Parameters characterizing the technical requirements for RNP APCH approaches}

\section{Precision}

The requirements for avionics used in aircraft for RNP APCH operations describe four basic parameters. For each parameter, there are strict guidelines that this equipment must meet. The RNP AR APCH is a global ICAO standard for instrument approach procedures to aerodromes where there are ground obstacles and / or significant operational benefits. These flights are more efficient thanks to optimal and repeatable approach paths. RNP AR also contributes to improving safety by replacing visual or imprecise risky approaches with it. These procedures require additional analysis, control and authorization. This is due to the strict criteria for the functioning of the RNP AR navigation characteristics, advanced aircraft equipment and adequate training of the crew.

Precision is a parameter that describes the maximum allowable difference between the aircraft position indicated by the navigation system and the actual position of the airplane. It is distinguished by horizontal and vertical precision.

During an RNP APCH operation in the final approach segment to LNAV or LNAV/VNAV minima, the total error of the horizontal navigation of the TSE system for at least $95 \%$ of the flight duration must not exceed $\pm 0.3 \mathrm{NM}$. The error along the track must also not exceed $\pm 0.3 \mathrm{NM}$ for at least $95 \%$ of the flight time. To ensure accuracy, the FTE piloting technique error should not exceed $\pm 0.25 \mathrm{NM}$ for $95 \%$ of the flight time. Accuracy is also affected by the navigation system error and route calculation error.

1. Altimetry System Error ASE

Each system must be designed and installed so that the indicated pressure height error for an ISA reference atmosphere does not exceed $\pm 80 \mathrm{ft}$ for an altitude not greater than $5,000 \mathrm{ft}$. Above sea level (excluding instrument calibration error). Additionally, for every 100 knots of the aircraft instrument speed, this error must not exceed $\pm 30 \mathrm{ft}$.

2. Horizontal Coupling Error HCE

This error should not exceed with a probability of $99.7 \% 24 \mathrm{ft}$ with a horizontal positioning accuracy of $0.05 \mathrm{NM}$ for at least $95 \%$ of the flight duration.

3. Flight Technical Error FTE

Vertical piloting error with a $99.7 \%$ probability should be less than $150 \mathrm{ft}$ along the glide path profile for an altitude of not more than 5,000 ft. Above sea level.

4. Equipment Error VNAV

VNAV on-board equipment error (excluding ASE, FTE, and HCE) shall be with a $99.7 \%$ probability less than $100 \mathrm{ft}$ along the glide path profile for an altitude of not more than $5000 \mathrm{ft}$. 


\section{Vertical Total System Error VTSE}

The total vertical error of the system (the square root of the sum of the squares of all errors above) with a probability of $99.7 \%$ should be less than or equal to $199 \mathrm{ft}$ for an altitude not greater than $5000 \mathrm{ft}$.

\section{Integrity and time to alerts}

Integrity is the second parameter used to describe navigation systems. The definition provided in ICAO Annex 10 is as follows: „A measure of the trust that can be placed in the correctness of the information supplied by the total system. Integrity includes the ability of a system to provide timely and valid warnings to the user (alerts)." It is very important to provide information to aircrew when the navigation system is not suitable for operational use (some parameter does not meet its guidelines). Therefore, integrity is determined by the probability of an error occurring over a period of time and the limiting value of the time to alert the user. During RNP APCH operations in the final approach segment of LNAV or LNAV/ VNAV minima, the system shall sound an alarm when the accuracy requirements are not met. The second factor for triggering an alert is the probability, greater than $1 \times 10^{-5}$ in an hour, that the TSE system's total horizontal navigation error will exceed 0.6 NM. A malfunction of an aircraft's navigation equipment is considered a major failure according to the airworthiness criteria. During operations on the final approach segment, the aircraft navigation equipment should alert, if there is a probability of more than $1 \times 10^{-5}$ within an hour, that an inaccurate position reading will occur or that the total system error levels will exceed 0.6 NM. The time to alarm should be a maximum of 10 seconds. For APV Baro-VNAV operations, integrity depends on system excellence, crew procedures, and the installation of additional on-board equipment independent of the VNAV system.

\section{Continuity}

The continuity parameter relates to the ability of the navigation system to function properly without the occurrence of unplanned interruptions during an intended operation. It is expressed in terms of the probability of a selected undesirable phenomenon occurring in time. Note that:

- the probability of losing the navigation information of the system is negligible (less than $1 \times 10^{-5}$ ),

- the probability of a permanent loss of navigation and communication functionality is extremely unlikely (less than $1 \times 10^{-9}$ ). 
LNAV and LNAV / VNAV functionality loss is considered a malfunction provided the aircraft is equipped with other navigation systems to reach the appropriate aerodrome. The operator should develop a fallback procedure in the event of any problems with the landing approach.

\section{Operation procedures}

According to Annex 10 to the Chicago Convention, the integrity of the GNSS system must be verified by ABAS (usually RAIM), SBAS or GBAS. The airspace organization should provide users with information on the anticipated temporary failure of the satellite system or the GNSS signal correctness monitoring and warning system (eg RAIM). Failure to do so would make it impossible to perform ABAS augmentation approach procedures. Therefore, for LNAV or LNAV / VNAV approaches, it is necessary to check the availability of RAIM in the information contained in NOTAM messages or the corresponding forecasting services. Insufficient satellite signals may be causing the RAIM function to temporarily not work. In the event of an expected loss of RAIM availability of more than 5 minutes, the flight plan should be revised (e.g. aircraft take off delay).

In Europe, a tool provided by EUROCONTROL called AUGUR is used for RAIM prediction. To generate an appropriate report, we need to enter the parameters of the target airport and aircraft equipment into the application:

- Mask Angle - it is the minimum elevation angle for which the satellite signal is available (it is not blocked by ground objects),

- Algorithms - there are available two version: FD Fault Detection (detects irregularities in the signal, requires 5 satellites to work) and FDE (detects anomalies and excludes them without causing RAIM unavailability, requires 6 satellites for operation),

- Level of integrity - the selection concerns the approach to landing (APPROACH RNP 0.3) or the arrival phase (TERMINAL RNP 1.0),

- Selective Availability - deliberate interference with the GPS signal by the US government until 2000. Old receivers still take the related error into account, which means that the indicated accuracy is lower (UNAWARE option). New GPS receivers are aware of the cessation of signal interference, which increases the accuracy of the indicated position (AWARE option),

- Barometric Augmentation - Integrity augmentation in GNSS systems provided by barometric altimeter data. It allows you to reduce the number of satellites used from five to four. 


\section{RNP AR APCH operations}

\section{Aircraft equipment requirements}

RNP AR operations are based on the use of RNAV area navigation equipment that determines the position of the aircraft in the LNAV level from data from a GNSS sensor. The VNAV vertical navigation system allows point-to-point flight along a vertical glide path that is recorded in the on-board navigation database. These points contain information about the altitudes at which the aircraft should intersect them and are additionally related to LNAV coordinates.

Aircraft avionics should comply with the requirements of RNP APCH approaches that provide horizontal and vertical guidance. The navigation system shall have the functionality to guide and maintain a flight path in an arc with a constant RF radius between two points. RNP capabilities, the Flight Director system and the autopilot should be capable of making the aircraft bank of 25 degrees more than 400 $\mathrm{ft}$ above the ground or bank angles of 8 degrees less than $400 \mathrm{ft}$. Any loss of precision required to perform an RNP AR approach with an accuracy better than RNP 0.3 must not occur. For this reason, the aircraft should be equipped with:

- duplicate sensors GNSS,

- duplicate Flight Management System,

- duplicate autopilot system,

- Inertial Reference Unit.

\section{Precision}

The system's total navigation error in the form of deviation from the track of aircraft operating RNP AR APCH approaches shall not exceed the required accuracy value ( $0.1 \mathrm{NM}$ to $0.3 \mathrm{NM}$ ) for $95 \%$ of the flight duration. Also, the error in determining the position along the track must not exceed the specified accuracy. The vertical system error consists of the error:

- height measurement,

- resulting from incorrect determination of the position of the aircraft along the road line,

- computing system,

- data precision,

- piloting techniques. 
The value of $99.7 \%$ of system errors during stabilized and continuous descent cannot exceed the values determined by the formula below (in feet):

$$
\begin{aligned}
& \sqrt{ }((6076,115) \cdot(1,225) \cdot R N P \cdot \tan \theta)^{2}+(60 \cdot \tan \theta)^{2}+75^{2}+ \\
& +\left(\left(-8,8 \cdot 10^{-8}\right) \cdot(\mathrm{h}+\Delta \mathrm{h})^{2}+\left(6,5 \cdot 10^{-3}\right) \cdot(\mathrm{h}+\Delta \mathrm{h})+50\right)^{2}
\end{aligned}
$$

where: RNP - precision required,

$\theta$ - glide path angle,

$\mathrm{h}$ - height of the pressure measuring station,

$\Delta \mathrm{h}$ - the height of the vessel above the station pressure measurement.

The $99.7 \%$ altimetry system error (ASE) for each aircraft in the approach configuration must not exceed the values given by the formula below (in feet):

$$
\text { ASE } \leq-8,8 \cdot 10-8 \cdot \mathrm{H} 2+6,5 \cdot 10-3 \cdot \mathrm{H}+50
$$

where: $\mathrm{H}-$ the true altitude of the aircraft.

Vertical guidance systems compliant with the requirements of RNP APCH approaches to LPV minima meet the stated conditions.

\section{Integrity, continuity and availability}

For integrity, the probability of the aircraft exceeding the horizontal and vertical minimum obstacle distances when performing RNP AR APCH procedures shall not exceed $1 \times 10^{-7}$ for each approach. In the continuity requirement it should be demonstrated that:

- the probability of losing all navigation information of the system is negligible (less than $1 \times 10^{-5}$ ),

- the probability of a permanent loss of navigation and communication functionality is extremely unlikely (less than $1 \times 10^{-9}$ ).

The aircraft operator must have a tool capable of forecasting the availability of an appropriate RNP signal quality at a specific place and time to properly perform the RNP AR APCH procedure. 


\section{Analysis of aircraft PBN equipment based on the CNS Dashboard application}

\section{Analysis of the PBN equipment of the aircraft of the airline A}

The analysis of aircraft equipment was carried out based on the CNS Dashboard application available from EUROCONTROL (Eurocontrol, 2021). It indicates the declared navigation capabilities of airplanes flying to European airports in a given period, based on ICAO flight plans sent by carriers to the Network Manager (air traffic management network) correlated with the PRISME Fleet 2 aircraft database. The research was carried out on the basis of scheduled flights of three airlines labelled A, B and C in 2018.

The analysed aircraft belonged to the standard-cost carrier designated as $\mathrm{A}$. Table 1 presents the PBN equipment of the aircraft of this air carrier. The available aircraft constituted $89 \%$ of the carrier's fleet were analysed. All the planes complied with the PNB navigation requirements. Only one aircraft was not equipped with a certified GNSS receiver (older Boeing 737-400). 77\% of aircraft have been adapted to perform LNAV / VNAV minima approaches, which are more favourable than just LNAV level guidance. None of the aircraft available in the fleet met the requirements for LPV minima approaches and RNP AR APCH approaches. Every fourth aircraft is adequately equipped to perform approaches based on the GBAS system.

Table 1. Analysis of the equipment of the aircraft of the airline A

\begin{tabular}{|c|c|c|c|c|c|}
\hline & DH8D & $\begin{array}{c}\text { E170/ } \\
\text { E175/E195 }\end{array}$ & B737 & B787 & Total result \\
\hline In accordance with PBN & $11(100 \%)$ & $26(100 \%)$ & $11(100 \%)$ & $8(100 \%)$ & $100 \%$ \\
\hline Receiver GNSS & $11(100 \%)$ & $26(100 \%)$ & $10(90,9 \%)$ & $8(100 \%)$ & $98 \%$ \\
\hline RNP APCH (only LNAV) & $0(0 \%)$ & $0(0 \%)$ & $0(0 \%)$ & $0(0 \%)$ & $0(0 \%)$ \\
\hline $\begin{array}{c}\text { APV BARO-VNAV (LNAV/ } \\
\text { VNAV) }\end{array}$ & $0(0 \%)$ & $26(100 \%)$ & $9(82 \%)$ & $8(100 \%)$ & $77 \%$ \\
\hline APV SBAS (LPV) & $0(0 \%)$ & $0(0 \%)$ & $0(0 \%)$ & $0(0 \%)$ & $0(0 \%)$ \\
\hline RNP AR APCH & $0(0 \%)$ & $0(0 \%)$ & $0(0 \%)$ & $0(0 \%)$ & $0(0 \%)$ \\
\hline GBAS & $0(0 \%)$ & $0(0 \%)$ & $5(45,5 \%)$ & $8(100 \%)$ & $23 \%$ \\
\hline Number of AC & 12 & 28 & 12 & 11 & \\
\hline
\end{tabular}

Source: Own study 


\section{Analysis of the PBN equipment of the aircraft of the airline B}

The analysed aircraft operated at Warsaw Modlin Airport and concerned low-cost, designated in the paper as type B. Table 2 shows the PBN equipment of air carrier B's aircraft. $54 \%$ of the air carrier's available aircraft were included in the analysis. All aircraft complied with the requirements for PBN navigation, had a GNSS receiver and met the requirements necessary to perform LNAV / VNAV minima approaches. The aircraft were not adequately equipped to conduct SBAS, RNP AR APCH and GBAS approaches.

Table 2. Analysis of the equipment of the aircraft of the airline B

\begin{tabular}{|c|c|c|c|}
\hline & & B737 & Obtained certification \\
\hline In accordance with PBN & & $232(100 \%)$ & YES \\
\hline GNSS & & $232(100 \%)$ & YES \\
\hline RNP APCH (only LNAV) & & $0(0 \%)$ & YES \\
\hline APV BARO-VNAV (LNAV/VNAV) & & $232(100 \%)$ & YES \\
\hline APV SBAS (LPV) & & $0(0 \%)$ & NO \\
\hline RNP AR APCH & & $0(0 \%)$ & NO \\
\hline GBAS & & $0(0 \%)$ & NO \\
\hline Number of AC & & 431 & \\
\hline
\end{tabular}

Source: Own study

\section{Analysis of the PBN equipment of the aircraft of the airline C}

The aircraft of the low-cost airline, designated in the article as $\mathrm{C}$, operated at Gdansk Airport. Table 3 presents the equipment of the PBN of the aircraft of the aviation carrier C. The analysis covered the available aircraft, which constituted $24 \%$ of the carrier's fleet (as of December 2018). All aircrafts were adapted to conduct PBN navigation, had a GNSS receiver and met the requirements necessary to perform LNAV/VNAV minima approaches. None of the carrier's aircraft was adequately equipped to conduct approaches using SBAS, RNP AR APCH and GBAS. 
Table 3. Analysis of the equipment of the aircraft of the airline $\mathrm{C}$

\begin{tabular}{|c|c|}
\hline & A320/A321 (23) \\
\hline In accordance with PBN & $23(100 \%)$ \\
\hline GNSS & $23(100 \%)$ \\
\hline RNP APCH (only LNAV) & $0(0 \%)$ \\
\hline APV BARO-VNAV (LNAV/VNAV) & $23(100 \%)$ \\
\hline APV SBAS (LPV) & $0(0 \%)$ \\
\hline RNP AR APCH & $0(0 \%)$ \\
\hline GBAS & $0(0 \%)$ \\
\hline Number of AC & 97 \\
\hline
\end{tabular}

Source: Own study

\section{Analysis of the PBN equipment of the analysed airlines}

The list of aircraft of A, B and C airlines that operated from Chopin Airport, Warsaw Modlin Airport and Gdansk Airport is presented in Table 4 and concerned 311 aircraft.

Table 4. Analysis of the equipment of aircraft

\begin{tabular}{|c|c|c|}
\hline & Number of equipped aircraft & Percentage of all aircraft \\
\hline In accordance with PBN & 311 & $100 \%$ \\
\hline GNSS & 310 & $99,68 \%$ \\
\hline RNP APCH (only LNAV) & 0 & $0 \%$ \\
\hline APV BARO-VNAV (LNAV/VNAV) & 298 & $95,82 \%$ \\
\hline APV SBAS (LPV) & 0 & $0 \%$ \\
\hline RNP AR APCH & 0 & $0 \%$ \\
\hline GBAS & 13 & $4,18 \%$ \\
\hline
\end{tabular}

Source: Own study

Table 4 shows the aggregate results for the aircraft equipment of the three air carriers that were analysed. The approaches to LNAV / VNAV minima are by far dominant in this comparison. However, there are no aircraft adequately equipped to perform SBAS approaches. 


\section{Analysis of the PNB equipment of aircraft operating at Chopin Airport}

The number of scheduled flights at Chopin Airport totaled 866 (as of December 2018).

Table 5. Analysis of equipment of aircraft operating at Chopin Airport

\begin{tabular}{|c|c|c|}
\hline & Number of equipped aircraft & Percentage of all aircraft \\
\hline In accordance with PBN & 866 & $100 \%$ \\
\hline GNSS & 834 & $96,30 \%$ \\
\hline RNP APCH (only LNAV) & 54 & $6,24 \%$ \\
\hline APV BARO-VNAV (LNAV/VNAV) & 716 & $82,68 \%$ \\
\hline APV SBAS (LPV) & 31 & $3,58 \%$ \\
\hline RNP AR APCH & 75 & $8,66 \%$ \\
\hline GBAS & 63 & $7,17 \%$ \\
\hline
\end{tabular}

Source: Own study

Table 5 presents the equipment of aircraft operating at Chopin Airport. Aircraft were not divided into air carriers. Based on this summary, you can see aircraft equipped to perform APV SBAS approaches to LPV and RNP AR APCH minima. However, their number in relation to the total number is small.

\section{Analysis of the PNB equipment of aircraft operating to ECAC countries in Q3 and Q4 in 2018}

Data for analysis were collected on the basis of ICAO flight plans, in which the destination airport was located in the territory of ECAC member countries.

Table 6. Analysis of equipment of aircraft operating to ECAC countries in III and IV part of 2018

\begin{tabular}{|c|c|c|c|}
\hline & Q3 2018 & Q4 2018 & Trend \\
\hline In accordance with PBN & $99,76 \%$ & $99,87 \%$ & $\nearrow$ \\
\hline GNSS & $96,43 \%$ & $96,77 \%$ & $\nearrow$ \\
\hline RNP APCH (only LNAV) & $11,22 \%$ & $11,14 \%$ & $\nearrow$ \\
\hline APV BARO-VNAV (LNAV/VNAV) & $73,09 \%$ & $74,10 \%$ & $\nearrow$ \\
\hline APV SBAS (LPV) & $1,31 \%$ & $1,62 \%$ & $\nearrow$ \\
\hline RNP AR APCH & $17,27 \%$ & $17,59 \%$ & $\nearrow$ \\
\hline GBAS & $7,17 \%$ & $7,76 \%$ & $\nearrow$ \\
\hline
\end{tabular}

Source: Own study 
Table 6 shows the totality of all aircraft flying to airports located in ECAC member countries. The third and fourth quarter of 2018 were compared in order to show the prevailing trends. Most of them tend to increase, which shows that the percentage of aircraft equipped to perform RNAV approaches is increasing

\section{Assessment of RNAV on-board equipment of aircraft for approach landing operations}

The data show that the adaptation of aircraft to perform PBN operations is now a common standard. The same can be said about equipping them with GNSS receivers. Only one of the 311 aircraft was unable to fly with the Global Navigation Satellite System. The number of these carriers equipped with receivers is likely so high because of the relatively young fleet.

The condition of the aircraft equipment is slightly worse in relation to the performance of RNP APCH approaches to LNAV / VNAV minima. Air carriers take care of equipping them with GNSS receivers with ABAS augmentation and a barometric altimeter. PANSA has introduced APV approach procedures with Baro-VNAV at as many as 12 Polish airports at all runway ends. For this reason, RNP APCH approaches are more operational for operational use than ILS approaches. Minima LNAV and LNAV/VNAV are also most common on approach cards at European airports. These are certainly factors encouraging air carriers to provide this possibility to aircraft in their fleet. The analysis shows that only air carrier A does not have all the aircraft equipped for the APV approaches from Baro-VNAV. These are two Boeing 737s and Bombardier Q400 planes that are very poorly equipped in terms of navigation. A growing trend can be observed in the number of aircraft equipped to perform LNAV/VNAV minima approaches. The analysis of air carriers indicated that most of the aircraft were equipped with barometric altimeters to enable APV Baro-VNAV approaches. The reason for this is the lower altitude at which the crew must make a decision to land, as opposed to level guidance only. This makes it easier to perform a landing approach in atmospheric conditions that lower visibility. In addition, it becomes possible to perform a flight with a fixed approach angle using vertical guidance, which is currently recommended by aviation organizations. Due to the presented reasons, the only downward trend in the analysis can be observed in the case of aircraft whose equipment allows flight to LNAV minima.

In the case of APV SBAS approaches to LPV minima, the current aircraft capabilities are poor. The aircraft of the analysed carriers do not have the appropriate equipment to perform such an operation. The results indicated that there were 31 aircraft at Chopin Airport that could perform LPV minima approach operations. They were Bombardier CSeries and Bombardier Q400. For example, Airbus currently offers only one type of aircraft with the ability to approach LPV minima, which is the A350 model [1]. Boeing does not yet have any machine capable of handling 
this technology. The reason for such a small percentage of APV-adapted SBAS aircraft may be the introduction of approach procedures using satellite augmentation only in the last few years. In June 2018, PANSA published the LPV200 approach procedures at twelve Polish controlled airports, which enable the descent to the decision height of 200 feet. These performances are comparable to the ILS category I. It should be noted, however, that procedures with LPV200 minima are available at all runway ends of the mentioned airports (ILS only at almost half of them). APV SBAS approaches certainly belong to the future of aviation and therefore one can expect more and more aircraft adapted to use this technology (as illustrated by a growing trend in the analysis).

The data shows that $8.66 \%$ of the aircraft landing at Chopin Airport in December 2018 were equipped with RNP AR APCH approaches. However, none of the analysed carriers have aircraft capable of performing this type of flights in their fleet. The reason may be a small number of airports adequately adapted to these operations (there is no airport in Poland). RNP AR APCH procedures are typically used at aerodromes with a complex and unsafe approach path. However, most major airports are located in land that is not constrained by ground obstacles. For this reason, RNP AR APCH approach procedures are rare. However, the number of aircraft with appropriate equipment for this type of flight is constantly growing. Airline A has aircraft adapted to GNSS based GNSS approaches with GBAS augmentation. These are new machines that have been purchased in recent years (Boeing 737 MAX 8 and 787). This decision is likely to pay off only in the future. Currently, no airport in Poland has published GLS approach procedures.

\section{Conclusions and discussion for further actions in the field of RNAV landing approach operations}

The Boeing is in the process of adapting its aircraft models to the technology that allows for landing approaches using SBAS augmentation. However, it is not known how long this process will take. The situation is better in terms of GLS (GBAS flights) approaches with this brand of aircraft.

The manufacturer announced that 72\% of new Boeing aircraft delivered in 2018 were equipped with the GLS system. In addition, the company announced that their machines are adapted to perform flights using a smooth transition between RNP during the arrival phase and GLS during the landing approach. Thanks to this, it is possible to fly by the technique of continuous descent and increase the separation between the aircraft. This also has a positive effect on the environment of the airport.

The European aircraft manufacturer Airbus proposed a concept called xLS. It allows the use of all available navigation technologies during landing (ILS, GBAS, SBAS, GNSS or conventional navigation aids). Thanks to this, it is possible to 
perform various types of landing approaches in a manner very similar to the commonly used ILS system. Both manufacturers saw a need to modify the avionics to accommodate GNSS approaches. Boeing offers avionics in its aircraft that exceeds the current standards of this technology. This equipment allows for GLS Category II and III approaches, but no ground station is yet available to provide the appropriate signal for their use. Airbus is in advanced work to implement equipment capable of carrying out SLS approaches.

The future of air navigation is based on GNSS. This is reflected in aviation law, the area of aircraft manufacturers, airport managers and air navigation agencies. Air carriers declare to equip their aircraft for the use of GNSS. The benefits of using air navigation are improving safety, efficiency, reliability, reducing costs and reducing the negative impact on the environment. The technology will continue to improve and will enable the introduction of a dual-frequency GNSS receiver from multiple satellite constellations. The benefit will be improved coverage and positioning accuracy. It is also believed that cybersecurity risks and undesirable disruptions will be reduced. However, the issue of developing such a receiver is about 5-10 years.

Unfortunately, new technology brings with it new risks. Due to the low strength of the GPS signal, ground-based sources transmitting on the same frequencies can disrupt the data provided to the aircraft. Such events contribute to the aborting of the GNSS approach operation. There are several types of sources that interfere with the satellite navigation signal:

- Personal Privacy Devices (PPD) - they are a GNSS signal blocking device to prevent location tracking. Placing them near the airport causes disruptions in the performance of operations,

- Protection of sensitive zones and VIP - specially installed devices interfering with the radio waves of the GNSS signal to protect sensitive areas and VIPs,

- GPS repeater - duplicates the GNSS signal to make it available in a place where there is usually no coverage (e.g. a hangar). May cause problems with signal reception for aircraft in the vicinity of such device,

- Radio wave station malfunction - there are known cases where the malfunction of the TV station interfered with the reception of the GNSS signal on board aircraft.

Apart from the presented sources interfering with the satellite navigation signal, a new concept can be distinguished - GNSS spoofing. This phenomenon consists in blocking the correct GNSS signal and transmitting a mimic signal that contains erroneous information. In the future, it will only be possible to use GNSS if all aircraft support this technology, and a procedure is published for each airport. 


\section{BIBLIOGRAFIA}

[1] Bailiwick of Jersey: Director of Civil Aviation, (2020). Performance Based Navigation (PBN) Approvals. Dostępne pod adresem: https://www.sesardeploymentmanager.eu/wp-content/ uploads/2016/12/07.-Manufacturer-perspective-Airbus-pdf.pdf [Dostęp dnia 10.10.2021].

[2] Boukfaoui EL, H., (2015). PBN Implementation from Industry perspective RNAV, RNP \& RNP AR. Dostępne pod adresem: https://www.icao.int/MID/Documents/2015/AFI-MID\%20 ASBU\%20Impl.\%20Workshop/2.1-3\%20AIRBUS\%20PBN\%20Impl. \%20from\%20Industry \%20 perspective.pdf [Dostęp 10.10.2021].

[3] Bousquet, C., Jacolot, F., Roturier, B., (2019). SBAS LPV flight procedure design and implementation. Dostępne pod adresem: https://www.icao.int/APAC/ Meetings/2019\%20 GBASSBAS/2-11_SBAS\%20LPV\%20flight\%20procedure\%20 design\%20and\%20implementation_Rev\%201(B\%20Roturier).pdf [Dostęp 10.10.2021].

[4] Dautermann, T., Mollwitz, V., Többen, H.H., Altenscheidt, M., Bürgers, S., Bleeker, O., Bock-Janning, S., (2015). Design, implementation and flight testing of advanced RNP to SBAS LPV approaches in Germany. Aerospace Science and Technology. Vol. 47, 280-290. DOI: https://doi.org/10.1016/j.ast.2015.09.035

[5] Eurocontrol, (2012). RNAV Approaches. Dostępne pod adresem: https://www.icao.int/EURNAT/ Other\%20Meetings\%20Seminars\%20and\%20Workshops/PBN\%20TF/PBN\%20TF8/PBNTF8\%20 IP08_RNAV\%20approaches.pdf [Dostęp 10.10.2021].

[6] Eurocontrol, (2021). CNS Dashboard. Dostępne pod adresem: https://ext.eurocontrol.int/analytics/saw.dll?dashboard [Dostęp dnia 10.10.2021].

[7] Eurocontrol, Required navigation performance approach. Dostępne pod adresem: https://www. eurocontrol.int/product/required-navigation-performance-approach [Dostęp 10.10.2021].

[8] Go£da, P., Zawisza, T., Izdebski, M., (2021). Evaluation of efficiency and reliability of airport processes using simulation tools. Eksploatacja i Niezawodnosc - Maintenance and Reliability, 23(4), 659-669. DOI: http://doi.org/10.17531/ein.2021.4.8.

[9] Go£DA, P., (2018). Selected decision problems in the implementation of airport operations. Scientific Journal of Silesian University of Technology. Series Transport, 101, 79-88. DOI: https:// doi.org/10.20858/sjsutst.2018.101.8.

[10] GoŁda, P., Zieja, M., (2015). Risk Analysis in Air Transport. Transport Means 2015, Pts I and Ii. Kaunas Univ Technology Press, Kaunas, 620-623.

[11] Guillet, R., (2019a). Concept and benefits of GBAS - SBAS. Dostępne pod adresem: https:// www.icao.int/APAC/Meetings/2019\%20GBASSBAS/1-2\%20Concept\%20and\%20Benefits\%20 of\%20GBAS\%20SBAS_post_final\% 20 (R\%20Guillet).pdf [Dostęp dnia 10.10.2021].

[12] Guillet, R., (2019b). Summary and Outcome of the GBAS SBAS Implementation Workshop. Dostępne pod adresem: https://www.icao.int/APAC/Meetings/2019\%20GBASSBAS/ Summary\%20 and $\% 20$ Outcome $\% 20$ of $\% 20$ the\%20GBAS\%20SBAS\%20Implementation\%20Workshop\%20(R\%20 Guillet)_final.pdf [Dostęp 10.10.2021].

[13] Hasegawa, T., Tsuchiya, T., Mori, R., (2015). Optimization of Approach Trajectory Considering the Constraints Imposed on Flight Procedure Design. Procedia Engineering. Vol. 99, 259-267. https://doi.org/10.1016/j.proeng.2014.12.534.

[14] International Civil Aviation Organization, (2018). Annex 10 to the Convention on International Civil Aviation, Aeronautical Telecommunications, Volume I. Radio Navigation Aids, Seventh Edition, Dostępne pod adresem: https://www.iacm.gov.mz/app/uploads/2018/12/an_10_v1_ Aeronautical-Telecommunications_7ed._2018_rev.91_01.07.18.pdf [Dostęp 10.10.2021]. 
[15] Jacyna, M., Wasiak, M., Lewczuk, K., Chamier-Gliszczyński, N., DĄBrowski, T., (2018). Decision problems in developing proecological transport system [Problemy decyzyjne ksztaltowania proekologicznego systemu transportowego]. Rocznik Ochrona Srodowiska, Vol. 20, $1007-1025$.

[16] JaCyna, M., WasiaK, M., LeWCZUK, K., Karoń, G., (2017). Noise and environmental pollution from transport: decisive problems in developing ecologically efficient transport systems. Journal of Vibroengineering, Vol. 19(7), 56395655. 10.21595/jve.2017.19371.

[17] Kaleta, W., Skorupski, J., (2019). A fuzzy inference approach to analysis of LPV-200 procedures influence on air traffic safety. Transportation Research Part C-Emerging Technologies, 106, 264 280. DOI:10.1016/j.trc.2019.07.001.

[18] Kowalski, M., Izdebski, M., Żak, J., GoŁda, P., Manerowski, J., (2021). Planning and management of aircraft maintenance using a genetic algorithm. Eksploatacja i Niezawodnosc - Maintenance and Reliability. Vol. 23, 143-153. https://doi.org/10.17531/ein.2021.1.15

[19] Kwasiborska, A., (2017). Sequencing landing aircraft process to minimize schedule length. Transportation Research Procedia, Vol. 28, 111-116. DOI:10.1016/j.trpro.2017.12.175.

[20] Kwasiborska, A., Skorupski, J., (2017). Operational restrictions for reducing noise and the safety of air operations. Zeszyty Naukowe. Transport - Politechnika Śląska, Vol. 94, 89-98. DOI:10.20858/sjsutst.2017.94.9.

[21] Novák, A., JŮN, F., ŠKultéty, F., Novák SedlačKová, A., (2019). Experiment Demonstrating the Possible Impact of GNSS Interference on Instrument Approach on RWY 06 LZZI. Transportation Research Procedia. Vol 43, 74-83. https://doi.org/10.1016/j.trpro.2019.12.021.

[22] Pyza, D., Jacyna-Go£da, I., Go£da, P., GoŁęBiowski, P., (2018). Alternative Fuels and Their Impact on Reducing Pollution of the Natural Environment. Rocznik Ochrona Środowiska, Vol. 20(1), 819-836.

[23] Rudyk, T., Szczepański, E., JaCyna, M., (2019). Safety factor in the sustainable fleet management model. Archives of Transport, 49(1), 103-114.

[24] Zieja, M., Smoliński, H., GoŁdA, P., (2015). Information systems as a tool for supporting the management of aircraft flight safety. Archives of Transport, Vol. 36(4), 67-76. DOI: $10.5604 / 08669546.1185211$. 